\title{
Sustainability in Project Management: Two Sides of the Same Coin or Poles Apart?
}

\author{
Jana KOSTALOVA ${ }^{1 *}$ and John McGRATH ${ }^{2}$ \\ 1 University of Pardubice, Pardubice, Czech Republic; jana.kostalova@upce.cz \\ 2 Technological University Dublin, Ireland; John.Mcgrath@TUDublin.ie \\ * Corresponding author: jana.kostalova@upce.cz
}

\begin{abstract}
Project management maturity influences the success of project management and project implementation. Based on project management international standards and other project management methodologies, various project management maturity models have developed. These models evaluate the level of project management maturity from many lenses; holistically, or in specific project management capabilities or specific to certain industry sectors. Projects are implemented in all human endeavors. Research and development, innovation initiatives, new ventures all harness projects as tool of change. Sustainability has three dimensions - social, economic and environmental. Project management is as much as life skill as it is a management science, relevant to business and society., It is therefore fundamental that sustainability is interwoven into project management tools, techniques and practices. Consequently, project management maturity models have to also evaluate how sustainability is included and applied in project management. The article defines a framework to assess sustainable project management in the form of the most important indicators based on the three pillars of sustainability: People, Planet and Profit. This approach could be used for evaluation of sustainability in project management generally or for the evaluation of a specific project management maturity model.
\end{abstract}

Keywords: project management maturity; project management maturity model; sustainable project management

\section{JEL Classification: O22; Q01}

\section{Introduction}

Societal attitudes regarding sustainability has changed in recent decades. Sustainability is just as relevant to ethics as it is to the environment and fundamental to tackling the greatest threat to humanity: Climate Change. It is concerned with limited natural resources, safeguarding the planet for future generations and unequivocal evidence that it is not possible to build society on endless growth and reduction of natural resources. Sustainability is the change of paradigm, which transforms human behavior and look for the way of life which could continue without dramatic and irreversible impact on society. There are many diverse views on this problem, but generally from 1992 the Rio de Janeiro World Summit it is the seriously presented and applicable attitude. (United Nations, 1992). 
Development of society is connected and concerned with research and innovation activities. These activities are mainly managed as projects. Based on theory and practice along with reflections on lessons learnt from past projects a suite of project management methodologies has been developed. There are currently three international standards of project management: available - Project Management Institute (PMI), International Project Management Association (IPMA) in the form of IPMA Competence Baseline and Project IN Controlled Environment (PRINCE2) and many other methodologies (Project Management Institute, 2017; International Project Management Association, 2020; Association for Project Management, 2019).

The success in implementing projects is very closely connected to project management maturity. The positive influence of project management methods and tools usage have been confirmed by number of studies such as Lappe and Spang (2014), Patanakul et al. (2010) or Meredith and Mantel (2012). As a tool to measure project management maturity the Project Management Maturity Models (PMMMs) have been developed (Kostalova \& Tetrevova, 2018; Spalek, 2015; Kwak et al., 2015).

There is an increasing swell from society demanding a more environmentally responsible approach in all project activities, there is increasing pressure to include a sustainable element in project management approaches (Silvius et al., 2012; McGrath \& Kostalova, 2020).

It is no longer realistic to measure Project success performance indicators that exclude sustainability and social responsibility. Lin et al. (2017) evaluated the social responsibility consideration in megaprojects, which by their very nature have a major impact on society and the environment. Silvius et al. (2012), Martens and Carvalho (2016) recommended the inclusion of sustainable considerations in project management as an integral component and evaluate the activities managed in project management from this point of view. There are available two Project Management Maturity Models/Standards focused on evaluation of the sustainability in project management: Sustainable Project Management Maturity Model (Silvius et al., 2012; Silvius \& Schipper, 2015) and 5P Standard in Sustainability in Project Management (Carboni et al., 2018; GPM, 2019).

The question is how to evaluate the presence of sustainable and socially responsible attitude in project implementation generally. One option is to assess the sustainability of project outputs, the other is to evaluate the project management procedures themselves and their contribution to sustainability i.e. via PMMMs. If PMMMs are the tools for measuring project management maturity, indicators that assess sustainable and socially responsible attitude should also be part of the assessed items within PMMMs.

The aim of the article is to select suitable indicators, based on the most relevant general sustainability assessment tools, identifying sustainable and socially responsible attitude in project environment. Via such list of sustainable indicators, it will be possible to evaluate project management in organization generally or available PMMMs. 


\subsection{Project Managament}

The Project Management Institute (2017) defines project management as applying knowledge, skills, tools and techniques to project activities to achieve project requirements. According to this standard, project management is accomplished through the application and integration of project management processes in the form of project initiation, planning, implementation, monitoring, verification and completion (Project Management Institute, 2017). So, via the project management methods, tools and recommended processes is possible to manage projects during the whole life cycle. To achieve success in all implemented projects it is suitable to specify appropriate processes in the form of methodology. This was the reason the international project management standards have been developed.

Based on the activities of project managers, practitioners and theorists under the support of the most important project management associations have been formed a conceptual theoretical framework for project management in the form of project management international standards. There are available three the most important standards - the Standard of the Project Management Institute, in the form of A Guide to the Project Management Body of Knowledge (Project Management Institute, 2017). The second important standard is Projects IN Controlled Environments2 (PRINCE2). It is a British standard managed by the Association for Project Management Group Ltd. (Association for Project Management, 2019). The third, mostly widespread standard mainly in European countries, is the IPMA Competence Baseline standard of the International Project Management Association, which is modify in national competence baselines standards (International Project Management Association, 2020). All standards offer methodology of project management, associations initiate research and development of their standards, education of project managers and certifications of their knowledge.

\subsection{Project Managament Maturity Models}

To evaluate project management maturity - level of development at which an organization project management processes are - Project Management Maturity Models (PMMMs) have been developed (Albrecht \& Spang, 2014; Souza \& Gomez, 2015; Brokes \& Clark, 2009). PMMMs are mainly based on international project management standards. Currently authors of the article identify 48 PMMMs worldwide. Many authors analyse PMMMs from different point of view, the structure of the models, but do not consider sustainability as an indicator of project management maturity (Farrokh \& Mansur 2013; Souza \& Gomes, 2015; Spalek, 2015; Albrecht \& Spang, 2016; Khoshgoftar \& Osman, 2009; Nenni et al., 2014).

Models are possible to structure from many points of view. Görög (2016) recommends evaluation the project management maturity at the project portfolio, program and individual project levels. There is a plethora of PMMMs available that focus on all levels - project portfolio, program and projects and PMMMs which evaluate only project level. Spalek (2015) divided PMMMs into process-oriented and organizational-oriented. Backlund et al. (2014) states that the characteristic focus of some PMMMs is to focus on assessing the capabilities or competencies of project managers, project team members, or top management so these 
models are competency-oriented PMMMs. Another point of view on PMMMs is based on specific areas which is via PMMM evaluated (construction projects, software development projects, risk project management etc.). Author structured PMMMs as follows:

- General PMMMs:

- Based on international project management standards (i.e. Organizational Project Management Maturity Model, based on PMI (Project Management Institute, 2013); Portfolio Management Maturity Model, based on PRINCE2 (Axelos, 2010); IPMA Delta Standard, based on IPMA (International Project Management Association, 2016))

- Based on project management methodologies (i.e. POC Competence Model (Gareis \& Huemann, 2000))

- Models focus on specific area of project management (i.e. Project Risk Maturity Model (Hopkinson, 2010); Conceptual Model for Assessing Project Management Maturity (Spalek, 2015); Sustainable Project Management Maturity Model (Silvius et al., 2012))

- Local project management models (i.e. Project management reference model in organizations from the Czech Republic (Adamek et al., 2013)).

\subsection{Sustainability and Project Management}

As a tool to respond to social change, environmental challenges and the impact of human activity on the environment and society, sustainable development can be considered as a model which offers the possibility of long-term sustainable existence of society without destructive interventions and changes in the environment. The sustainable development is the balance between economic growth, social wellbeing and wise use of natural resources (Keating, 1993).

Sustainable development means meeting the needs of the present whilst ensuring future generations can meet their own needs. It has three pillars: economic, environmental and social, known as Triple-Bottom Line. To achieve sustainable development, policies in these three areas have to work together and support each other. (European Commission, 2020; Elkington, 1998).

The term of sustainability in business environment is very closed to Sustainable Development (Martens \& Carvalho, 2016), Corporate Social Responsibility (European Commission, 2001) or Corporate Sustainable Management (Baumgartner \& Rauter, 2017), Corporate Sustainability (Baumgartner and Ebner 2010) and Business Ethics (Carroll, 1991; Baumgartner \& Rauter, 2017).

The assessment of sustainability or corporate socially responsible behavior of organizations in public or private sector is possible via many available tools. There are declared sustainable development goals in the form of Agenda 2030 by United Nations (2015) and Local Agenda 21 by United Nations (1992), international standards like Global Reporting Initiative (GRI) (GRI, 2016), UN Global Compact (2014), AA 1000 Accountability (2018), the OECD Guidelines for Multinational Enterprises (2011), SA 8000 (Social Accountability International, 2014), or ISO 26000 (ISO 26000, 2010). There are also available sustainability 
maturity models like Business Sustainability Maturity Model (Cagnin, Loveridge, \& Butler, 2005), Maturity Model for Sustainability in New Product Development (Hynds et al, 2014), model measured Business Sustainability Maturity Levels (Meza-Ruiz et al. 2017).

Sustainability must be made operational in each specific context, at scales relevant for its achievement, and appropriate methods must be designed for its long-term measurement (Heinen, 1994). Sustainability is reflected in all areas, and therefore it has to be included also in the project management.

Traditionally the project management success was measured by many criteria, methods, indicators, tools. Silvius and Schipper (2016) present the overview of success criteria and they also connect the area of projects, project success and sustainability. The Martens and Carvalho (2016) summarized the overview of articles focused on relationship of sustainability and project management and declared the sustainability has got positive impact on project success. Carvalho and Rabechini (2017) presented sustainability from other point of view as the new dimension of project success, which is necessary to evaluate. Many other authors also discussed the mutual relationship of sustainability and project management and the benefits that can be gained by including of sustainability in project management (Silvius \& Schipper, 2016; Silvius et al. 2012, Martens \& Carvalho, 2016, Wang, Wei \& Sun, 2014; Carboni et al., 2018; GPM, 2019).

\subsection{Indicators of Sustainability}

Sustainability Assessment can be powerful tool to analyze how the sustainability in all three pillar dimensions is implemented (Waas et al., 2014; Ali, 2013). Specification of indicators of sustainability as the tools to evaluate the level of sustainability, was made by many authors (Waas et al., 2014, Bell \& Morse, 2008; Matravers, Moldan, Billharz, \& Robyn, 1998; Hak, Moldan \& Dahl, 2007). The structured sustainable indicators in form of dimensions or criteria are presented in the international standards of sustainability (see chapt. 1.3).

Agenda 2030 (United Nations, 2015) defined 17 goals in area of sustainable development, these goals are important, and widely accepted as criteria for detailed assessment of sustainability. GRI structured the indicators for assessment in three areas - economic, social and environmental (GRI, 2016) and in each of them specify the detail indicators. UN Global Compact (2014) structured the indicators in four areas - human rights, working conditions, environment and anti-corruption activity.

AA 1000 Accountability (2018) specify recommendations for public and private companies in area of sustainability, they presented mainly principles of sustainable attitude - principle of inclusivity, principle of materiality, principle of responsiveness and principle of impact. The OECD Guidelines for Multinational Enterprises (2011) focus mainly on global companies and specify recommendation in areas: human rights, employment, environment, combating bribery, consumer interests, competition, taxation. SA 8000 (Social Accountability International, 2014) focuses mainly on corporate ethics, in this standard the detail areas of ethics, work conditions and labour rights are specified. ISO 26000 (ISO 26000, 2010) as the base of the standard presents the core subjects of social responsibility and sustainability - 
organization governance, labour practices, the environment, fair operating practices, consumer issues and community involvement and development.

Sustainable indicators based on international initiatives and standards offer general sustainable indicators. Lin et al. (2017) presented sustainability indicators suitable to evaluate the megaprojects social responsibility, the indicators are structured in five groups economic, legal, ethical and environmental, political and social responsibility, they are used for responsibility assessment on project or organizational level. Banishashemi et al. (2017) specify the critical success factors for integration of sustainability into construction project management, the factors correspond with the project environment, but they focus mainly on large infrastructure projects.

\section{Methodology}

The purpose of this paper is to develop a framework to support the integration of sustainability into project management maturity assessment. In order to identify the links between sustainably and project management a review of the literature was conducted specifically focused on sustainable project management and the integration of sustainability into project management methodologies and maturity assessments. As the most important resources focused generally on indicators of sustainability have been chosen general standard indicators (GRI, 2016), which presents the overview of indicators of sustainability. These indicators have been evaluated and modified from the point of relevance to project management. The list of project management indicators has been extended based on the most suitable analysis of sustainability in project management, which are presented mainly in resources (Martens and Carvalho, 2016; Lin et al., 2017; Banishashemi et al., 2017) and the recommended way of evaluation of sustainability in business activities (Meza-Ruiz et al., 2017). The final list of indicators of sustainability is usable to evaluate the sustainable attitude in organization project management attitude or available project management maturity models.

The literature provides evidence of a direct correlation between project performance and project management maturity but also exposes the integration of sustainability into project management maturity is a relatively new phenomenon that is relatively unexplored. Indisputably, there is a lack of frameworks in the context of integrating sustainability into project management maturity. This paper and the proposed framework contribute to this emerging research topic that is relevant to both practitioners and academics.

\section{Results}

To analyse the involvement of sustainable attitude in PMMMs based on literature review the indicators of sustainability which are relevant in context of PMMM evaluation were specified. As the source mainly the GRI standard (2016), Meza-Ruiz et al. (2017), Martens and Carvalho (2016), Lin et al. (2017) and Banishashemi et al. (2017) have been used. The sustainability indicators are structured in accordance with Triple-bottom line in three main areas and the additional area for general indicators. The list of indicators of sustainability is presented in Table 1. 
Table 1. Sustainability Indicators for PMMMs assessment.

\begin{tabular}{|c|c|}
\hline \multirow{21}{*}{ General Sustainability Indicators } & Managerial Approach \\
\hline & Business Ethics \\
\hline & Innovation Management \\
\hline & Organizational Culture Management \\
\hline & Responsibility for Product and Services \\
\hline & Assessment of Technological Feasibility of Project \\
\hline & Improvement \\
\hline & Obey Law and observe disciplines \\
\hline & Ensure Quality and Safety \\
\hline & Philanthropy \\
\hline & Transparent Information and Reporting \\
\hline & Green Designing and Construction \\
\hline & Collaboration \\
\hline & Implementing an Effective Quality Control \\
\hline & Implementing an Effective Project Risk Management \\
\hline & Strategic Management \\
\hline & Knowledge Management \\
\hline & Awareness of Sustainability \\
\hline & No Conflict of Interest \\
\hline & Effective Project Control \\
\hline & Lessons Learned Focused on Sustainability \\
\hline \multirow{16}{*}{$\begin{array}{l}\text { Economic Sustainability } \\
\text { Indicators }\end{array}$} & Assessment of Economic Feasibility of Project \\
\hline & Financial and Economic Performance \\
\hline & Financial Benefits from Good Social and Environmental Practices \\
\hline & Ensure Shareholders Economic Interest \\
\hline & Market Presence \\
\hline & Indirect Economic Impacts \\
\hline & Transparent and competitive procurement processes \\
\hline & Anti-corruption \\
\hline & Anti-competitive Behavior \\
\hline & Tax \\
\hline & Cost Management \\
\hline & Increase in Profitability \\
\hline & Reasonable Return on Investment \\
\hline & Perpetuation of Environmental Benefit of the Project \\
\hline & Efficiency Utilize Resources \\
\hline & Recycling of Resources \\
\hline \multirow{14}{*}{$\begin{array}{c}\text { Environmental Sustainability } \\
\text { Indicators }\end{array}$} & Nature Resources Minimization \\
\hline & Materials Minimization \\
\hline & Energy Minimization \\
\hline & Water and Effluents Minimization \\
\hline & Ground, Ground Pollution \\
\hline & Air, Air Pollution \\
\hline & Biodiversity \\
\hline & Emissions \\
\hline & Waste Management \\
\hline & Environmental Compliance \\
\hline & Supplier Environmental Assessment \\
\hline & Eco-efficiency \\
\hline & Management of Environmental Impacts \\
\hline & Environmental Policy Management \\
\hline
\end{tabular}




\begin{tabular}{|c|c|}
\hline & Environmental Commitment and Responsibility \\
\hline & Protect Environment \\
\hline \multirow{30}{*}{ Social Sustainability Indicators } & Employment \\
\hline & Labor/Management Relations \\
\hline & Occupational Health and Safety \\
\hline & Training and Education \\
\hline & $\begin{array}{l}\text { Support and cooperation of Project Management Team in } \\
\text { delivering a sustainable project }\end{array}$ \\
\hline & Diversity and Equal Opportunity \\
\hline & Non-discrimination \\
\hline & Freedom of Association and Collective Bargaining \\
\hline & Child Labor Forced or Compulsory Labor \\
\hline & Security Practices \\
\hline & Rights of Indigenous People \\
\hline & Human Rights Assessment \\
\hline & Local Communities/Relationship with Society \\
\hline & Relationship with Stakeholders \\
\hline & Relationship with Suppliers and Contractors \\
\hline & Supplier Social Assessment \\
\hline & Public Policy \\
\hline & Community involvement \\
\hline & Customer Health and Safety \\
\hline & Customer Relationship Management \\
\hline & Marketing and Labeling \\
\hline & Customer Privacy \\
\hline & Socioeconomic Compliance \\
\hline & Participation and Involvement of Stakeholders \\
\hline & Impact on the Professional Life of the Team Members \\
\hline & Satisfaction and Productivity of the Team \\
\hline & Perpetuation of Social Benefit of the Project \\
\hline & Motivation \\
\hline & Human Capital Development \\
\hline & Corporate Citizenship \\
\hline
\end{tabular}

Authors based on the GRI standard (2016), Meza-Ruiz et al. (2017), Martens and Carvalho (2016), Lin et al. (2017) and Banishashemi et al. (2017)

\section{Conclusions}

Project management trends are driven by business trends and the development of the society. In this new world era, sustainable development is recognized as a pillar of high performance, ethics and a contributor to bottom-line profitability and return of investment (ROI). The project management community can no longer ignore this reality and must pivot to recognize sustainability as a building block of project management maturity. Project management maturity and sustainability are relatively new concepts but both, along with the planet prosper by a mutual recognition of their symbiotic relationship.

This study has planted a seed for further research into the concept of sustainability as a building block of project management maturity and sustainable attitudes within the project management community and project-oriented organizations. 


\section{References}

AccountAbility. (2018). AA1000 Accountability Principles. https://www.accountability.org/wpcontent/uploads/2018/05/AA1000_ACCOUNTABILITY_PRINCIPLES_2018_Single_Pages.pdf

Adamek, M., Bartoš, D., Buchbauerová, M., Doležal, J., \& Motal, M. (2013). Project management reference model in organizations. Společnost pro projektové ř́izení.

Albrecht, J. C., \& Spang, K. (2014). Linking the benefits of project management maturity to project complexity. International Journal of Managing Projects in Business, 7, 285-301. https://doi.org/10.1108/IJMPB-08-2013-0040

Albrecht, J. C., \& Spang, K. (2016). Disassembling and reassembling project management maturity. Project Management Journal, 47(5), 18-35. https://doi.org/10.1177/875697281604700503

Ali, M. (2013). Sustainability Assessment. Academic Press.

Association for Project Management. (2019). APM Body of Knowledge (7th ed.). Association for Project Management.

Axelos Limited. (2010). P3M3 project management self-assessment. https://www.axelos.com/Corporate/media/Files/P3M3\%20Model/P3M3_Self_Assess_Project.pdf

Backlund, F., Chronéer, D., \& Sundqvist, E. (2014). Project Management Maturity Models - a Critical Review a Case Study within Swedish Engineering and Construction organizations. Procedia - Social and Behavioral Sciences, 119, 837-846. https://doi.org/10.1016/j.sbspro.2014.03.094

Banishashemi, S., Hosseini, M. R., Golizadeh, H., \& Sankaran, S. (2017). Critical success factors (CSFs) for integration of sustainability into construction project management practices in developing countries. International Journal of Project Management, 35(6), 1103-1119. https://doi.org/10.1016/j.jproman.2017.01.014

Baumgartner, R. J., \& Rauter, R. (2017). Strategic perspectives of corporate sustainability management to develop a sustainable organization. Journal of Cleaner Production, 140, 81-92. https://doi.org/10.1016/J.JCLEPRO.2016.04.146

Baumgartner, R. J., \& Ebner, D. (2010). Corporate sustainability strategies: sustainability profiles and maturity levels. Sustainable Development, 18, 76-89. https://doi.org/10.1002/sd.447

Bell, S., \& Morse, S. (2008). Sustainability Indicators Measuring the Immeasurable? (2nd ed.). Earthscan.

Brokes, N., \& Clark, R. (2009). Using Maturity Models to Improve Project Management Practice. In POMS 20th Annual Conference. 011-0288 (pomsmeetings.org)

Cagnin, C. H., Loveridge, D., \& Butler, J. (2005). Business sustainability maturity model. In Business Strategy and the Environment Conference (pp. 4-6). Microsoft Word - Cagnin.doc (crrconference.org)

Carboni, J., Duncan, W., Gonzalez, M., Milsom, P., \& Young, M. (2018). Sustainable Project Management: The GPM Reference Guide (2nd ed.). GPM Global.

Carroll, A. B. (1991). The pyramid of corporate social responsibility: Toward the moral management of organizational stakeholders. Business Horizons, 34, 39-48.

Carvalho, M. M., \& Rabechini, R. (2017). Can project sustainability management impact project success? An empirical study applying a contingent approach. International Journal of Project Management, 35(6), 11201132. https://doi.org/10.1016/j.ijproman.2017.02.018

Elkington, J. (1999). Cannibals with Forks: the Triple-Bottom Line of 21st Century Business. New Society Publishers. John Wiley \& Son.

European Commission. (2020). What is sustainable development? https:/ec.europa.eu/trade/policy/policymaking/sustainable-development/

European Commission. (2001). Green Paper: Promoting a European Framework for Corporate Social Responsibility. Luxemburg: Office for Offical Publications of the European Communities. COM (2001).

Farrokh, J., \& Mansur, A. K. (2013). Project management maturity models and organizational project management maturity model (OPM3): A critical morphological evaluation. International Scholarly and Scientific Research \& Innovation, 7(5), 68-71.

Gareis, R., \& Huemann, M. (2000). Project management competencies in the project-oriented organization. In J. R. Turner, \& S. J. Simister (Eds.), Gower Handbook of Project Management (3rd ed., pp. 709-722) Gower.

GRI. (2016). GRI: 2016. https://www.globalreporting.org/standards/gri-standards-download-center/?g=e10f8b5a6775-40da-afbf-4b3cdc1df635

Görög, M. (2016). A Broader Approach to Organizational Project Management Maturity Assessment. International Journal of Project Management, 34(8), 1658-1669. https://doi.org/10.1016/j.ijproman.2016.08.011

GPM. (2019). The GPM P5 ${ }^{\mathrm{TM}}$ Standard for Sustainability in Project Management GPM Global Version 2.0. GPM Global.

Hak, T., Moldan, B., \& Dahl, A. L. (2007). Sustainability indicators: a scientific assessment. Island Press. 
Heinen, J. T. (1994). Emerging, diverging and converging paradigms on sustainable development. International Journal of Sustainable Development and World Ecology, 1, 22-33. https://doi.org/10.1080/13504509409469857

Hopkinson, M. (2010). The project risk maturity model. Routledge. https://doi.org/10.4324/9781315237572

Hynds, E. J., Brandt, V., Burek, S., Jager, W., Knox, P., Parker, J. P., Schwartz, L., Taylor, J., \& Zietlow, M. A. (2014). Maturity Model for Sustainability in New Product Development. Research-Technology Management, 57(1), 50-57. https://doi.org/10.5437/08956308X5701143

International Project Management Association. (2020). IPMA Standards. https://www.ipma.world/individuals/standard/

International Project Management Association. (2016). Reference model for IPMA Delta. http://www.ipma.world/certification/certify-organisations/delta-reference-model/

ISO. (2010). ISO 26 000:2010 Guidance on social responsibility. https://www.iso.org/obp/ui/\#iso:std:iso:26000:ed1:v1:en

Keating, M. (1993). The Earth Summit's Agenda for Change. Chentre for our Comon Future.

Khoshgoftar, M., \& Osman, O. (2009). Comparison of maturity models. 2nd IEEE International Conference on Computer Science and Information Technology. IEEE. https://doi.org/10.1109/ICCSIT.2009.5234402

Kostalova, J., \& Tetrevova, L. (2018). Proposal and Verification of Project Management Methods and Tools Oriented Maturity Model, Revista de Gestão e Projetos Journal of Business and Projects, 9(1), 1-23. https://doi.org/10.5585/gep.v9i1.595

Kwak, Y. H., Sadatsafavi, H., Walewski, J., \& Williams, N. L. (2015) Evolution of project based organization: A case study. International Journal of Project Management, 33(8), 1652-1664. https://doi.org/10.1016/j.ijproman.2015.05.004

Lappe, M., \& Spang, K. (2014). Investment in project management are profitable: A case study-based analysis of the relationship between the costs and benefits of project management. International Journal of Project Management, 32(4), 603-612. https://doi.org/10.1016/j.ijproman.2013.10.005

Lin H., Zeng, S., Ma, H., Zeng, R., \& Tam, V. W. T. (2017). An indicator system for evaluating megaproject social responsibility. International Project Management Journal, 35, 1415-1425. https://doi.org/10.1016/j.ijproman.2017.04.009

Martens, M. L., \& Carvalho, M. M. (2016). The challenge of introducing sustainability into project management function: multiple-case studies. Journal of Cleaner Production, 117, 29-40. https://doi.org/10.1016/j.jclepro.2015.12.039

Matravers, R., Moldan, B., \& Billharz, S. (1998). Sustainability Indicators: Report of the Project on Indicators of Sustainable Development. John Wiley.

McGrath, J., \& Kostalova, J. (2020). Project management trends 2020+. In Hradec Economic Days (pp. 534-542). https://doi.org/10.36689/uhk/hed/2020-01-061

Meredith, J. R., \& Mantel, S. J. (2012). Project management a managerial approach (8th ed.). John Wiley \& Sons.

Meza-Ruiz, I. D., Rocha-Lona, L., Soto-Flores, M. R., Garza-Reyes, J. A., Kumar, V., \& Lopez-Torres, G. C. (2017). Measuring Business Sustainability Maturity-levels and Best Practices. Procedia Manufacturing, 11, 751-759. https://doi.org/10.1016/j.promfg.2017.07.176

Nenni, M. E., Arnone, V., Boccardeli, P., \& Napolitano, I. (2014). How to Increase the Value of the Project Management Maturity Model as a Business-oriented Framework. International Journal of Engineering Business Management, 6(8), 1-7, https://doi.org/10.5772/58292

OECD. (2011). OECD Guidelines for Multinational Enterprises. OECD Publishing. https://doi.org/10.1787/9789264115415-en

Patanakul, P., Iewwongcharoen, B., \& Milosevic, D. (2010). An empirical study on the use of project management tools and techniques across project life-cycle and their impact on project success. Journal of General Management, 35(3), 41-65. https://doi.org/10.1177/030630701003500304

Project Management Institute. (2017). A Guide to the Project Management Body of Knowledge (6th ed.). PMI.

Project Management Institute. (2013). Organizational project management maturity model (OPM3) (3rd ed.). PMI. https://doi.org/10.1201/9781420028942.axa

Silvius, A. J. G., \& Schipper, R. (2015). Developing a maturity model for assessing sustainable project management. Journal of Modern Project Management, 3(1), 16-27.

Silvius, G., \& Schipper, R. (2016). Exploring the relationship between sustainability and project success conceptual model and expected relationships. International Journal of Information Systems and Project Management, 4(3), 5-22. https://doi.org/10.12821/ijispm040301 
Silvius, G., Schipper, R., Planko, J., Brink, J., \& Köhler, A. (2012). Sustainability in Project Management. Gower Publishing Limited.

Spalek, S. (2015). Establishing a conceptual model for assessing project management maturity in industrial companies. International Journal of Industrial Engineering, 22(2), 301-313.

Social Accountability International. (2014). Social Accountability 8000: International standard. (SA8000: 2014). http://www.sa-intl.org/_data/global/files/SA8000Standard2014(3).pdf

Souza, T. F., \& Gomes, C. F. S. (2015). Assessment of maturity in project management: a bibliometric study of main models. Procedia Computer Science, 55, 92-101. https://doi.org/10.1016/j.procs.2015.07.012

UN Global Compact. (2014). Guide to Corporate Sustainability. https://www.unglobalcompact.org/docs/publications/UN_Global_Compact_Guide_to_Corporate_Sustainability.pdf

United Nations. (1992). Earth Summit Agenda 21. United Nations.

United Nations. (2015). Transforming our world: the 2030 Agenda for Sustainable Development. United Nations Official Document.

Waas, T., Hugé, J., Block, T., Wright, T., Benitez-Capistros, F., \& Verbruggen, A. (2014). A. Sustainability Assessment and Indicators: Tools in a Decision-Making Strategy for Sustainable Development. Sustainability, 6(9), 5512-5534. https://doi.org/10.3390/su6095512

Wang, N., Wei, K., \& Sun. H. (2014). Whole life project management approach to sustainability. Journal of Management in Engineering, 30(2), 246-255. https://doi.org/10.1061/(ASCE)ME.1943-5479.0000185 